J. Product. \& Dev., 18(3):475 - 494 (2013)

\title{
GENETIC IMPROVEMENT OF EGG PRODUCTION TRAITS IN DOKKI-4 STRAIN. 2-CORRELATED RESPONSES, HERITABILITY, GENETIC AND PHENOTYPIC CORRELATIONS FOR BODY WEIGHT RAITS.
}

\author{
H. H. Younis; F. A. Abdel-Ghany* and Nasra B. Awadein* \\ Poultry Production Department, Faculty of Agriculture, Kafr Elsheikh \\ University, Egypt. \\ * Animal Production Research Institute, Agriculture Research Center, \\ Ministry of Agriculture, Egypt.
}

\section{ABSTRACT:}

This present study was carried out during three successive generations to improve body weight through selection in developed Dokki-4 chicken strain and to study correlated response of some economic traits. The chicks in each generation represented two lines, selected line for high body weight and control line. The results showed that body weight at different ages studied were improved in selected more than control line $(P<0.01)$. There were significant differences $(P<0.05)$ between generations, lines and sexes body weight $(B W)$, daily weight gain $(D G)$, feed conversion (FC), and body weight measurements (shank length, keel length and body circumference) at 4, 8, and 12 weeks.

Selection differentials of male 12-weeks body weight were 71.0 gm and $57 \mathrm{gm}$ in the selected generations. The corresponding values for females were $54.0 \mathrm{gm}$ and $48.0 \mathrm{gm}$. The cumulative realized and expected responses, were $130.3 \mathrm{gm}$ and $28.16 \mathrm{gm}$ for males, and were $83.9 \mathrm{gm}$ and $22.4 \mathrm{gm}$ for females over two generations, respectively. The cumulative realized response to selection for body weight was 26.01, 58.0 and 81.95 for body weight at 4, 8 and 12 weeks of age , 0.92, 1.14, 0.94 and 1.03 for daily weight gain, 0.31, 0.82 and 1.46 for shank length, keel length and body circumference at 12 weeks, while, were with feed conversion $-0.89,-1.27$ and -1.32 at 4,8 and 12 weeks of age.

Heritability estimates based on sire component of variance (first and second generation) for all traits studied were ranged between high, medium and low values. Positive genetic and phenotypic correlations were found body weight at 12 weeks of age and body weight at different ages, daily weight gain, and body measurements (shank length, keel length and 
body circumference), the range between the values of high, medium and low. But among body weight and feed conversion were negative.

In conclusion, the high positive correlation obtained in this study indicate that an improvement in body weight might lead to an improvement in other traits and body measurements. This is a good indicator of body conformation and may be used in selection programmer.

Key words: Dokki-4 strain, correlated responses, heritability, genetic \& phenotypic correlations, body weight traits.

\section{INRODUCTION}

In Egypt, as in most countries, poultry production plays an important role in providing customers with animal protein. Egyptian poultry industry depends mainly on importing commercial parent stocks for both meat and egg production. Several attempts have been made to improve the performance of local breeds of chickens in Egypt (El-Itriby and Sayed, 1966; Mahmoud et al. . 1982; Abdel-Gawad, 1981 and Abdel-Gawad et al., 1983).

Growth can be regarded as a direct fitness trait that increases productive efficiency and thereby decrease production costs (Iraqi et al., (2013).

Egyptian strains of chickens were not subjected to intensive selection program and consequently, high additive and non-additive genetic variations appeared among them (Khalil et al., 1999, Iraqi et al., 2000). Early growth and maturity has been considered as important fecundity and hereditary traits. Genetic selection for increased body weight has resulted in significant gain in chickens (chambers et al., 1981). In selection program, the additive genetic variation represents about $30 \%$ of the total phenotypic variation in growth measurements (El-Hossari, 1970 and Siegel and Dunnington, 1985). The individual selection is effective for traits that exhibited high heritability estimates as body weight (Rishell, 1997). Variations of $h^{2}$ estimates were reported concerning body weight at different ages (Kosba et al., 2002 and 2006; Saleh et al., 2002; Abdou, 2006). Genetic and/or phenotypic correlations among production and reproduction traits have been studied by Balat et al. (1995), Francesch et al. (1997), Hartmann et al. (2003) working on foreign strains of chickens and those using local strains were El-Wardany and Abdou (1993), Younis and Abd-El Ghany (2004) and Abdella (2006).The genetic gain in a selected trait could be determined in standard deviation units (Harvey and Bearden, 1962) or by the difference between the mean of selected group and population mean (Falconer, 1981). 
Therefore, the aim of this study is to select for body weight at 12 weeks of age in Dokki-4 strain of chickens and measure the direct response from individual selection for improved 12-week body weight. Moreover, the estimation of some genetic parameters such as heritability estimates, genetic and phenotypic correlations coefficients.

\section{MATERIALS AND METHODS}

Data of hatching records for Dokki-4 chickens were obtained from three successive generations at the Poultry Research Center, Poultry Production Department, Faculty of Agriculture, Kafr Elsheikh University, in collaboration with the Animal Production Research Institute, Agriculture Research Center, Ministry of Agriculture, Egypt, to improve body weight through selection in developed Dokki-4 chicken strain and to study correlated response of some economic traits. Data of hatching records for Dokki-4 chickens were obtained from three successive generations. The study involved 2425 pedigreed chicks obtained from the mating 85 sires with 800 dams through three successive breeding generations, one line individually selected (SL) for high body weight, based on body weight at 12 weeks of age, control line (CL). Birds weighted equal or more than mean of population were selected as parent stock for next generation here after. The number studied chicks for high body weight 1740 in selected line and 685 for control line. Chicks were wing banded and individually weighted at hatch according to each line and transferred to brooding house till 12 weeks of age. All chicks were reared under nearly similar conditions of management over generations and provided the same standard of feeding, lighting and vaccinations.

\section{The studied traits:}

1- Body weight $(\boldsymbol{B W})$ : Individual body weight to the nearest gram was recorded at hatch (BW0), four weeks (BW4), eight weeks (BW8) and twelve weeks (BW12) of ages.

2- Daily weight gain (DG): DG during intervals of 0-4, 4-8 and 8-12 weeks of age.

3- Feed conversion (FC): It was calculated every four weeks at, 4, 8 and 12 weeks of age.

$$
\mathrm{FC}=\mathrm{F} 1 / \mathrm{DG}
$$

Where: $\mathrm{FC}=$ Feed conversion, $\mathrm{F} 1=$ Feed intake during a certain period for individual bird, $\mathrm{DG}=$ Weight gain during a certain period. 
4- Body measurements (shank length, keel length and body circumferences): These were measured at 4,8 and 12 weeks of age to the nearest centimeter.

- Shank length : ( the distance from leg pad to the tarsus bone).

- Keel length : The keel bone length that breast meat gathering upon it forming breast fillet.

- Body circumferences: Around then breast from the front of keel bone and under the wings.

Selection differential (S): It was calculated as the difference between the average of the selected birds as parents for a certain trait and the average of their population (Falconer, 1983).

The realized direct and correlated responses: These were estimated according to the numerator of the following equation after Guill and Washburn (1974) for estimating realized heritability.

$\mathrm{R}=($ Progeny selected $\mathrm{X}-$-Parent selected $\mathrm{X})$-(Progeny control X-Parent control X).

The expected response to selection $(\boldsymbol{E R})$ : It was calculated according to the general equation (Falconer, 1983).

$\mathrm{ER}=$ Selection differential $(\mathrm{S}) \mathrm{x}$ Heritability $\left(\mathrm{h}^{2}\right)$.

Statistical analysis was done by using Harvey program (1990) and statistical fixed model was used as follows:

Yijkl $=\mu+\mathrm{Gi}+\mathrm{Lj}+\mathrm{Sk}+\left(\mathrm{G}^{*} \mathrm{~L}\right) \mathrm{ij}+(\mathrm{L} * \mathrm{~S}) \mathrm{jk}+\left(\mathrm{G}^{*} \mathrm{~S}\right) \mathrm{ik}+\left(\mathrm{G}^{*} \mathrm{~L} * \mathrm{~S}\right) \mathrm{ijk}+\mathrm{eijk} \mathrm{l}$ Where: Yijkl $=$ an observation; $\mu=$ Overall mean; $\mathrm{Gi}=$ Effect of generation; $\mathrm{Lj}=$ Effect of line; $\mathrm{Sk}=$ Effect of sex; $\left(\mathrm{G}^{*} \mathrm{~L}\right) \mathrm{ij}=$ Interaction between generation and line; $\left(\mathrm{L}^{*} \mathrm{~S}\right) \mathrm{jk}=$ Interaction between line and sex; $\left(\mathrm{G}^{*} \mathrm{~S}\right) \mathrm{ik}=$ Interaction among generation and sex; $\left(G^{*} \mathrm{~L} * \mathrm{~S}\right) \mathrm{ijk}=$ Interaction among generation, line and sex, eijkl= Random error

The heritability, genetic, and phenotypic correlations estimates were performed according to the following Model: (Harvey, 1990).

$$
\mathrm{Y}_{\mathrm{ijk}}=\mu+\mathrm{G}_{\mathrm{i}}+\mathrm{S}_{\mathrm{ij}}+\mathrm{D}_{\mathrm{ijk}}+\mathrm{e}_{\mathrm{ijk}}
$$

Where: $Y_{i j k}=$ An observations; $\mu=$ Overall mean; $G_{i}=$ Fixed effect of $i^{\text {th }}$ generation; $\mathrm{S}^{\mathrm{ij}}=$ Random effect of the $\mathrm{j}^{\text {th }}$ sire within $\mathrm{i}^{\text {th }}$ generation; $\mathrm{D}_{\mathrm{ijk}}=$ Random effect of the $\mathrm{k}^{\text {th }}$ dam within $\mathrm{i}^{\text {th }}$ sir, within $\mathrm{j}^{\text {th }}$ generation; $\mathrm{e}_{\mathrm{ijk}}=$ Random error.

Differences between each two means were done according to Duncan's Multiple Range Test (Duncan, 1955). 


\section{RESULTS AND DISCUSSION}

\section{Direct Response:}

Selection differential $(\mathrm{S})$, realized response $(\mathrm{R})$ and expected responses (ER) during the two generations of selection were recorded in Table 1. Selection differential of body weight at 12 weeks of age were 71 and $57 \mathrm{~g}$ for males and $54 \mathrm{~g}$ and 48 for females for base and second generations. The realized responses were $101.8 \mathrm{~g}$ and $28.5 \mathrm{~g}$ of males and $67.2 \mathrm{~g}$ and $16.7 \mathrm{~g}$ of females for first and second generations. Moreover, cumulative selection responses of body weight at 12 weeks of age after two generations of selection were 130.3 and $83.9 \mathrm{~g}$ for males and females, respectively.

Expected response to selection was 28.16 for males and 22.24 for females in two generations. The present results were agreement with those obtained by Abd El-Halim (1999) were 35.6g and 27.1g, while the realized responses were 3.9 and $12.2 \mathrm{~g}$ for males and females, respectively, after two generations of selection for high body weigh in Alexandria chicken at 12 weeks of age. Saleh et al., (2008) estimated that selection differentials of males at 12-week body weight were 57.4, 44.6 and $18.6 \mathrm{~g}$ in the base, first and second selected generations. The corresponding values for females were $56.7,14.5$ and $6.8 \mathrm{~g}$ in El-Salam chicken at 12 weeks of age. The realized and expected responses, were $105.3 \mathrm{~g}$ and $37.4 \mathrm{~g}$ for males, and were $75.6 \mathrm{~g}$ and $24.2 \mathrm{~g}$ for females over three generations, respectively. Selection response for males was higher compared to females, which could be explained through the higher selection differential for males than females.

These results indicated that the selected line showed significantly higher body weight than the control line. Similar results were reported by ElTahawy (2000), Kosba et al., (2002a); Abd El-Ghany (2006) and Saleh et al., (2008), found that body weight for males were heavier than females, as well as selected line was heavier than control line and generations for Inshas and El- Salam strain which selected individually based on body weight at 12 weeks of age;

Highly significant differences $(\mathrm{P}<0.01)$ were found among generations. The body weight at second generation was higher compared with the base population and first generation. Moreover, selected line had significantly ( $P$ $<0.001)$ higher body weight than the control line. Moreover, highly significant differences were observed between males and females as well as the interaction between generation $\mathrm{x}$ lines and generation $\mathrm{x}$ line $\mathrm{x}$ sex. These interactions may be due to that the change in body weight was not equal per generation. 
Table 1: Last square means \pm standard errors of body weight at 12 weeks of age for selected and control lines as well as selection differentials $(\mathrm{S})$, realized response (R) and expected responses ( ER ) during the two generations of selection.

\begin{tabular}{|c|c|c|c|c|c|c|c|}
\hline \multirow[t]{2}{*}{ Generations } & \multicolumn{2}{|c|}{ Selected line } & \multicolumn{2}{|c|}{ Control line } & \multirow{2}{*}{$\begin{array}{l}\mathbf{S} \\
(\mathrm{g})\end{array}$} & \multirow{2}{*}{$\begin{array}{c}\mathbf{R} \\
(\mathrm{g})\end{array}$} & \multirow{2}{*}{$\begin{array}{c}\text { ER* } \\
(\mathrm{g})\end{array}$} \\
\hline & no & $\mathbf{X} \pm$ S.E & no & $\mathrm{X} \pm$ S.E & & & \\
\hline \multicolumn{8}{|c|}{ Males } \\
\hline Base generation & 196 & $825.3 \pm 8.32$ & 72 & $828.0 \pm 5.50$ & 71 & & \\
\hline $1^{\text {st }}$ generation & 220 & $899.6 . \pm 9.05$ & 112 & $800.5 \pm 5.78$ & 57 & 101.8 & 15.62 \\
\hline $2^{\text {nd }}$ generation & 219 & $952.4 \pm 10.08$ & 103 & $825.2 \pm 6.45$ & & 28.5 & 12.54 \\
\hline $\begin{array}{l}\text { Cumulative } \\
\text { response }\end{array}$ & & & & & & 130.3 & 28.16 \\
\hline \multicolumn{8}{|c|}{ Females } \\
\hline Base generation & 354 & $785.0 \pm 9.11$ & 128 & $727.0 \pm 5.32$ & 54 & & \\
\hline $1^{\text {st }}$ generation & 360 & $819.0 \pm 8.86$ & 173 & $752.0 \pm 5.10$ & 48 & 67.2 & 11.88 \\
\hline $2^{\text {nd }}$ generation & 391 & $864.0 \pm 9.77$ & 97 & $734.0 \pm 6.11$ & & 16.7 & 10.56 \\
\hline $\begin{array}{l}\text { Cumulative } \\
\text { response }\end{array}$ & & & & & & 83.9 & 22.44 \\
\hline
\end{tabular}

\section{Correlated response: \\ 1. Body weight:}

Least- square means for body weight at different ages as affected by sex, line and generations are presented in Table 2. It was observed that there were highly significant differences between generations, lines and sex at 4,8 and 12 weeks of age. The first and second generations, chickens of selected line had heavier weight than the control line and the differences among lines (Gen.). The differences among line (generation) were highly significant ( $\mathrm{p}<$ 0.05). Body weight of males was heavier than females at different ages except at hatch. These results are agreement with those obtained by El-Hanoun (1995); Nawar et al. (1995); Abd- Alla (1997); Kosba et al. (1997); Mohammed (1997); Kosba et al. (2002a); Abd El-Ghany (2006); Saleh et al. (2008). There were no significant differences between sex at hatching time but the differences become significant from 4 up to 12 weeks of age. Generally, selection for high body weight at different ages resulted positive changes for males and females. Similar results were reported by Kosba et al. (2002); ElEdel (2005) and Abd El- Ghany (2006).

Interactions among generation, line and sex were significant in most traits. These results are in agreement with those obtained by Afifi (1994); ElTahawy (2000); Abd El-Ghany (2006) ; Saleh et al., (2008). 
The realized correlated responses as positive values for body weight at 4, 8, and 12 weeks of age for four weeks of age were $16.08 \mathrm{gm}\left(1^{\text {st }}\right.$ gen.), $9.93 \mathrm{gm}\left(2^{\text {nd }}\right.$ gen.) and $26.01 \mathrm{gm}$ ( cumulative response ), for eight weeks of age were $31.38 \mathrm{gm}\left(1^{\text {st }}\right.$ gen.), $26.62 \mathrm{gm}$ ( $2^{\text {nd }}$ gen.) and $58.00 \mathrm{gm}$ ( cumulative response ), and for twelve weeks of age were $46.70 \mathrm{gm}\left(1^{\mathrm{st}} \mathrm{gen}.\right), 35.25 \mathrm{gm}$ $\left(2^{\text {nd }}\right.$ gen.) and $81.95 \mathrm{gm}$ ( cumulative response), respectively (Table 6).

This finding indicated that positive change of body weight at different ages expected with the advancement of selection for body weight at 12 weeks of age.

\section{Daily weight gain}

Least-squares means for daily weight gain at different ages, (0-4), (4$8)$ and (8-12) as affected by sex, line and generation are presented in Table 3. The first and second generations, chicken of selected line had heavier weight gain than the control line and the differences among lines (Gen.) and between generations highly significant. These results are agreement with these obtained by (Saleh and Farghaly 1988), Aifi (1994), Abd El-Halim (1999) and El Tahawy (2000). Daily weight gains at different periods in base generation were significantly less mean these of the first and second generation. Chickens of selected line had heavier daily weight gain than the control line and the differences between lines and between generations were highly significant. Males body weight had higher gain than females at different periods.

Interaction among generations, lines and sex were highly significant in most traits. These results are agreement with these obtained by Saleh and Farghaly (1988), Abd El-Halim (1999), El-Tahawy (2000), Abd El-Ghany (2006) and Saleh et al. (2008).

The realized correlated responses as positive value for body weight gain at (0-4), (4-8), and (8-12) weeks of age for period one were $0.56 \mathrm{gm}\left(1^{\text {st }}\right.$ gen.), $0.36 \mathrm{gm}$ ( $2^{\text {nd }}$ gen.) and $0.92 \mathrm{gm}$ (cumulative response), for period 2 were $0.55 \mathrm{gm}\left(1^{\text {st }}\right.$ gen. $), 0.59 \mathrm{gm}\left(2^{\text {nd }}\right.$ gen.) and $1.14 \mathrm{gm}$ (cumulative response), for period 3 were $0.63 \mathrm{gm}\left(1^{\text {st }}\right.$ gen. $), 0.31 \mathrm{gm}\left(2^{\text {nd }}\right.$ gen.) and 0.94 gm (cumulative response) as shown in Table 6. This finding indicates that positive change of body weight gain at different ages could be expected with the advancement of selection for body weight at 12 weeks of age.

Generally, these results indicated that direct selection for increasing body weight at 12-weeks of age in Dokki-4 strain of chickens had an affects on growth rate during growing period after two generations of selection. 


\section{Feed conversion:}

Least-Squares means for feed conversion at different ages 4, 8and 12 weeks of age for males, females and combined sexes by lines and generations are presented in Table 4. The first and second generations, chickens of selected line had a significant $(\mathrm{P}<0.05)$ improvement in feed conversion compared with control line. Significant differences were found between selected and control lines as well as among generations for feed conversion during he different ages. Moreover, selected line had better feed conversion than control line in the first and second generations during the different ages. The differences among line (generation), sex were highly significant $(\mathrm{P}<$ 0.01). Males had better feed conversion than females at different ages.

The interaction between generations and lines was high significant. These results confirm hose reported by Saleh et al., (1994), Nawar et al., (1995); Kosba et al., (2002); Abd El-Ghany (2006) and Saleh et al. (2008).

The realized correlated response for feed conversion at 4, 8 and 12 weeks of age as a result of selection for body weight at 12 weeks of age were negative value for traits. The first period was $-0.63 \mathrm{gm}\left(1^{\mathrm{st}}\right.$ gen. $),-0.26 \mathrm{gm}$ ( $2^{\text {nd }}$ gen.) and $-0.89 \mathrm{gm}$ (cumulative response), for the second period was $0.87 \mathrm{gm}\left(1^{\text {st }}\right.$ gen. $),-0.40 \mathrm{gm}\left(2^{\text {nd }}\right.$ gen.) and $-1.27 \mathrm{gm}$ (cumulative response), and for the third period was $-0.98 \mathrm{gm}\left(1^{\text {st }}\right.$ gen. $),-0.34 \mathrm{gm}\left(2^{\text {nd }}\right.$ gen. $)$ and -1.32 gm (cumulative response), respectively as shown in Table 6.

\section{Body measurements:}

Least square means for body measurements (shank length, Keel length and body circumference) at 4, 8 and 12 weeks of age per generation, line and se are given in Table 5. It was shown that there were highly significant differences between generations, lines and sexes at 4, 8 and 12 weeks of age. Body measurements for selected line had the longest than control line. Highly significant differences $(P<0.01)$ between selected and control lines at different periods were detected for values of body measurements in females being lower than males in both selected and control line. Therefore, sex differed significantly in body measurements a pouting period. The interaction between generations and lines was high significant. These results confirm those reported by Saleh et al. (1994) , El-Wardany et al., (1994), Rizkalla et al., (2002), Abd el-Ghany (2006), and Saleh et al., (2008 a \& b), they reported that body circumference related to live body weight. From these results in the present study, it could be concluded that the improvement of body weight affected body measurements in a positive direction. 
YOUNIS et al. 
The interaction between generations, lines and sex was high significant. These results confirm hose reported by Saleh et al., (1994), Nawar et al., (1995), Kosba et al., (2002), Abd El-Ghany (2006) and Saleh et al., (2008).

The realized correlated response for body measurements at 4, 8 and 12 weeks of age as a result of selection for body weight at 12 weeks of age were positive value for traits. Period 3 (12 weeks) were $0.16 \mathrm{~cm}\left(1^{\text {st }}\right.$ gen. $), 0.15 \mathrm{~cm}$ ( $2^{\text {nd }}$ gen.) and $0.31 \mathrm{~cm}$ (cumulative response) for shank length, $0.32 \mathrm{~cm}\left(1^{\text {st }}\right.$ gen.), $0.50 \mathrm{~cm}\left(2^{\text {nd }}\right.$ gen.) and $0.82 \mathrm{~cm}$ (cumulative response) for keel length and $0.65 \mathrm{~cm}\left(1^{\text {st }}\right.$ gen. $), 0.81 \mathrm{~cm}\left(2^{\text {nd }}\right.$ gen.) and $1.46 \mathrm{~cm}$ (cumulative response) for body circumference, respectively ( Table 6).

Table 6: Realized correlated response for other traits in selected line by generation

\begin{tabular}{|l|c|c|c|}
\hline \multirow{2}{*}{ Traits } & \multicolumn{2}{|c|}{ Generations } & \multirow{2}{*}{ Total } \\
\cline { 2 - 3 } & First & Second & \\
\hline Body weight at 4 weeks & 16.08 & 9.93 & 26.01 \\
Body weight at 8 weeks & 31.38 & 26.62 & 58.00 \\
Body weight at 12 weeks & 46.70 & 35.25 & 81.95 \\
Body weight gain at (0 -4 weeks) & 0.56 & 0.36 & 0.92 \\
Body weight gain at ( 4- 8 weeks) & 0.55 & 0.59 & 1.14 \\
Body weight gain at (8 - 12 weeks) & 0.63 & 0.31 & 0.94 \\
Feed conversation at (0-4) weeks & -0.63 & -0.26 & -0.89 \\
Feed conversation at (4-8) weeks & -0.87 & -0.40 & -1.27 \\
Feed conversation at ( 8-12) weeks & -0.98 & -0.34 & -1.32 \\
Shank length at 12 weeks & 0.16 & 0.15 & 0.31 \\
Keel length at 12 weeks & 0.32 & 0.50 & 0.82 \\
Body circumference at 12 weeks & 0.65 & 0.81 & 1.46 \\
\hline
\end{tabular}

\section{Heritability:}

The estimated of heritability $\left(\mathrm{h}^{2}\right)$ were obtained according to sire variance component of body weight traits for selected line presented in Table 7. The $\mathrm{h}^{2}$ for body weight at hatch was high $\left(0.47 \pm 0.03\right.$ and $0.49 \pm 0.13$ for $1^{\text {st }}$ and $2^{\text {nd }}$ gen.). Similar results were reported in Fayoumi chicks by Amer (1965), Iraqi et al., (2000) and Abd El-Ghany (2006). The $\mathrm{h}^{2}$ for body weight 
Table 7: Estimates of heritability from sire $\left(h^{2} s\right)$ for body weigh at different ages and some of traits and correlations (genetic and phenotypic) between body weight a 12 weeks of age and other traits for second generations in Dokki-4 selected line.

\begin{tabular}{|l|c|c|c|c|}
\hline \multicolumn{1}{|c|}{ Traits } & \multicolumn{2}{c|}{ Heritability } & \multicolumn{2}{c|}{ Correlations } \\
\cline { 2 - 5 } & First Gen. & $\begin{array}{c}\text { Second } \\
\text { Gen. }\end{array}$ & rG & rP \\
\hline Body weight at hatch & $0.47 \pm 0.03$ & $0.49 \pm 0.13$ & $0.41 \pm 0.23$ & 0.38 \\
Body weight at 4 weeks & $0.21 \pm 0.09$ & $0.24 \pm 0.11$ & $0.37 \pm 0.09$ & 0.24 \\
Body weight at 8 weeks & $0.16 \pm 0.12$ & $0.18 \pm 0.07$ & $0.34 \pm 0.11$ & 0.27 \\
Body weight at 12 weeks & $0.20 \pm 0.14$ & $0.19 \pm 0.16$ & -- & -- \\
Body weigh gain at 4 weeks & $0.31 \pm 0.11$ & $0.28 \pm 0.08$ & $0.22 \pm 0.08$ & 0.41 \\
Body weigh gain at 8 weeks & $0.29 \pm 0.14$ & $0.34 \pm 0.16$ & $0.19 \pm 0.06$ & 0.35 \\
Body weigh gain at 12 weeks & $0.39 \pm 0.17$ & $0.36 \pm 0.12$ & $0.26 \pm 0.07$ & 0.33 \\
Feed conversation at 4 weeks & $0.22 \pm 0.01$ & $0.19 \pm 0.03$ & $-0.39 \pm 0.11$ & -0.22 \\
Feed conversation at 8 weeks & $0.24 \pm 0.05$ & $0.24 \pm 0.01$ & $-0.44 \pm 0.21$ & -0.35 \\
Feed conversation at 12 weeks & $0.21 \pm 0.02$ & $0.24 \pm 0.02$ & $-0.48 \pm 0.12$ & -0.39 \\
Shank length at 12 weeks & $0.39 \pm 0.08$ & $0.42 \pm 0.06$ & $0.25 \pm 0.09$ & 0.38 \\
Keel length at 12 weeks & $0.59 \pm 0.09$ & $0.55 \pm 0.11$ & $0.41 \pm 0.14$ & 0.40 \\
Body circumference at 12 weeks & $0.61 \pm 0.07$ & $0.63 \pm 0.01$ & $0.59 \pm 0.06$ & 0.49 \\
\hline
\end{tabular}

at 4,8 and 12 weeks of age were $0.21 \pm 0.09,0.16 \pm 0.12$ and $0.20 \pm 0.14\left(1^{\text {st }}\right.$ generation), $0.24 \pm 0.11,0.18 \pm 0.07$ and $0.19 \pm 0.16 \quad\left(2^{\text {nd }}\right.$ generation $)$, respectively. Heritability for body weights at different ages were low values compared to observed for the other studies. However, these results of heritability are agreement with those reported by Abd El-Latif and ElHammady (1992 b), Ghanem (2003), who reported that heritability values of body weight in local strains of chicken ranged from 0.13 to 0.66 . Ghanem (1995), Abd El-Halim (1999), El-Tahawy (2000), Abd El-Ghany (2006) and Saleh et al. (2008). Adeleke et al. (2011) found the heritability of body weight at 4,8 and 12 weeks of age $(0.020,0.39$ and 0.45$)$.

Heritability $\left(\mathrm{h}^{2}\right)$ for daily weight gain at 4,8 and 12 weeks of age were moderate $0.31 \pm 0.11,0.29 \pm 0.14$ and $0.39 \pm 0.17$ (first generation), $0.28 \pm 0.08$, $0.34 \pm 0.16$ and $0.36 \pm 0.12$ (second generation), respectively. Similar results 
were recorded by Iraqi et al. (2000) for Golden Montazah and Abd El-Ghany (2006) for Inshas.

Estimates of $\mathrm{h}^{2}$ for feed conversion at 4,8 and 12 weeks of age were moderate $0.22 \pm 0.01,0.24 \pm 0.05$ and $0.21 \pm 0.02$ ( $1^{\text {st }}$ generation $), 0.19 \pm 0.03$, $0.24 \pm 0.01$ and $0.24 \pm 0.02\left(2^{\text {nd }}\right.$ generation $)$, respectively, Similar results were recorded by Abd El-Ghany (2006).

Estimates of $\mathrm{h}^{2}$ for body measurements (Shank length, keel length and body circumference) at 12 weeks of age are presented in Table 7. Most body measurements under study were generally found to be moderate to high. The values estimated were $0.39 \pm 0.08,0.59 \pm 0.09$ and $0.61 \pm 0.07$ ( $1^{\text {st }}$ generation), $0.42 \pm 0.06,0.55 \pm 0.11$ and $0.63 \pm 0.01$ (second generation), respectively, Similar results were recorded by Abd El-Ghany (1992) El-labban (1999), Mallik et al. (2003) , Abd El-Ghany (2006) and Salah et al., (2008), Adeleke et al., (2011) found the heritability of shank length at 4,8 and 12 weeks of age $(0.92,0.70$ and 0.52 ), and keel length at 4,8 and 12 weeks of age ( $0.01,0.63$ and 0.02 ).

\section{Genetic and phenotypic correlation:}

The genetic and phenotypic correlation among body weight at 12 weeks of age with body weight at different ages, daily weight gain, body measurements (shank length, keel length and body circumference at 12 weeks of age), are presented in Table 7, it was estimated that in most cases there were positive and highly significant genetic and phenotypic correlations between body weight at different ages. These result well agreed with those reported by Hanan (1995) in Fayoumi, Abd El-Ghany (2006) in Inshas strain and Salah et al., (2008) in El-Salam strain. The genetic and phenotypic correlation among body weight at 12 weeks of age with daily gain and some growth rate traits and body measurements (shank length, keel length and body circumference at 12 weeks of age) were positive. Similar results were recorded by Abd El-Gawad and El-Ibiary (1972); El-Labban (1999); Abd ElGhany (2006) and Salah et al., (2008). While, the genetic and phenotypic correlation among body weight at 12 weeks of age with feed conversion were negative.

In general, positive genetic and phenotypic correlations were found between body weight at 12 weeks of age with body weight at different ages and daily weight gain, body measurements (shank length, keel length and body circumference) at 12 weeks of age and most growth rate trait, while was negative value with feed conversion.

In conclusion, the high positive correlation obtained in this study indicate that an improvement in body weight might lead to an improvement in 
other traits and body measurements. This is a good indicator of body conformation and may be used in selection programmer.

\section{REFERENCES}

Abd-Alla, M.A.H. (1997). Independent culling levels selection for improving body weight and feed conversion in chicken. M.Sc. Thesis. Fac of Agric., Alex. Univ., Egypt.

Abd El-Gawad,E.M., (1981). Mandarah,a new breed of chickens. Egypt Poult. Sci., 1: 16-22.

Abdel- Gawad, E.M..; and H.M. El- Ibiary (1972). Heterosis estimates for some economic traits in the Fayoumi and RIR. Crosses. Agric. Res. Rev. Egypt, 50: 79-84

Abd El-Gawad, E.M., Magda M. Balat, Nazla Y. Abo El-Ela, M. M. Ali and K. M. Omran (1983). "El-Salam" A new locally developed strain of chickens. Agric. Res. Rev. , 61: 147-156.

Abd El- Ghany, F. A. (1992).Genetically and nutritional studies on poultry. M.Sc. Thesis, ac. Of Agric., Tanta ,Uni. Egypt.

Abd El-Ghany, F.A., (2005): Selection for improving some economic traits in developed Inshas chickens strain. Journal Of Productivity And Development, 10 (2); 195-210.

Abd El-Ghany, F.A., (2006): Genetic studies for growth traits in Inshas strain. J. Agric. Sci. Mansoura Univ., 31 (2): 1301-1313.

Abd El-Halim, H.A. (1999): Selection and genetic analysis of some meat and egg production traits in local chickens. M.Sc. Thesis, Fac. of Agric., Alex. Univ., Egypt.

Abd-Ella, M. M. M. (2006): Heritability and Genetic correlation of feed efficiency and some egg production traits in Baheij chicken strain. M. Sci. Thesis, Fac. of Agric. Alex. Univ., Saba-Bash, Egypt.

Abdellatif, M. A., (1999). Selection for body weight at eight weeks of age in Dandarawi chicken. 1-Direct and correlated responses in growth measurements. Egypt. Poult. Sci., 19 (111) : 35-52.

Abdel-Latif, M. A. and H. Hammady (1992). Heritability of some egg production and egg quality traits in Dandarawi chickens. Egypt Poult.Sci., 12:751-764.

Abdou, A.M. (2006). Effect of selection for 8-week body weight of male broiler parents on the performance and genetic parameters of their progeny. Egypt. Poult. Sci., 26 (111) 1217-1240. 
Adeleke, M A, S O Peters2, M O Ozoje, C O N Ikeobi, A M Bamgbose1 and Olufunmilayo A Adebambo (2011) Genetic parameter estimates for body weight and linear body measurements in pure and crossbred progenies of Nigerian indigenous chickens. Livestock Research for Rural Development 23 1)

Afifi, y. k. (1994). Acceptability of some agro-by products by different local chicken strains. Ph. D. Thesis, Fac. Of Agric Alex. Univ. Egypt

Aly, O.M., Hanan, H. Ghanem, Yousria, K.Afifi, Nazla, Y.Abou El-Ella and Magda, M.Balat, (2010-a). Selection for improving egg production in Mandarah chickens. 4-Direct and correlated response for some economic traits for four generations of selection. Egypt. Poult. Sci., 30: 137-156.

Amer, M.F. (1965). A comparison of sexual maturity age and egg weight between standard breed and Fayoumi chickens in sub-tropics. Poult. Sci., 44: 1180-1189.

Balat, Magda, M.; Nadia A. El-Sayed; F.N. Soliman; and M.A. Kosba (1995). The effect of introducing dwarf gene to Mandarah strain on economically important traits. Egypt. Poult. Sci., 15: 43-71

Duncan, D.B. (1955). Multiple range and multiple F- test. Biometrics, 11:1-42.

El-Edel, M.A.,(2005). Breeding for immune response in Egyptian chicken strains.M.Sc. Thesis, Fac. Vet. Alex. Univ., Egypt.

El-Itriby, A.A.and I.F., Sayed, 1966. "Dokki 4" A new breed of poultry. Agric. Res. Rev., Cairo; 44: 102-109

El-Hanoun, A.M. (1995). Effect of crossing among four Egyptian strains of chicken on growth and production traits. M.Sc. Thesis. Fac. Of Agric., Alex. Univ., Egypt.

EL-Hossari, M. A. And M. T. Ragab (1970). Correlated responses to selection for high body weight at 8 weeks of age in a closed flock of Fayoumi fowl. U. A. R. J. Anim. Prod., 10:37-42.

El-Khaiat, I. A. (2008). Comparative study among to established lines, their cross and others under local condition. M. Sc. Thesis, Faculty of Agric., Kafrel-Sheikh Univ. Egypt.

El-Tahawy, W.S. (2000). Genetically improvement of some productive and reproductive traits in local chicken. M. Sc. Thesis. Fac. of Agric., Alex. Univ., Egypt.

El-Wardany, A.M.and Abdou, F.H. (1993). Genetic analysis of two strains of Norfa chickens under selection for egg number or size.2-Expected realized correlated respo0nse. Minufia J. Agric. Res., 18 (1): 241-256. 
El-Wardany, A.M.; Gohoer, L.M.; and Ali, W.Z. (1994). Correlated responses of body weight and measurements under selection for weight in some local breeds of chickens. Egypt. Poult. Sci., 14: 5 1-70.

Enayat, A.H., (2006). Selection for increasing egg production characters in two local strains of chickens. M.Sc.Thesis, Fac. Of Agric., Kafr ElSheikh Tanta Univ. Egypt.

Falconer, D.S.(1983). Introduction to quantities genetics. longman Ins. New York.

Francesch, A; J. Estany; L. Alfonso and M. Iglesias (1997). Genetic parameters for egg number, egg weight, and eggshell color in three Catalan poultry breeds. Poult Sci., 76(12):1627-31.

Ghanem, Hanan H.A. (1995). Selection for age at sexual maturity in Alexandria chickens. M. Sc. thesis, Fac. Of Agric., Alex. Univ., Egypt.

Ghanem, H.H. (2003). Selection for low egg Yolk cholesterol level and correlated response for some economic traits in some native type strains. Ph. D. Thesis, Fac. of Agric. Alex. Uni., Egypt

Guill, R.A.; and K.W. Washburn (1974). Genetic changes in efficiency of feed utilization of chickens maintaining body weight constant. Poult. Sci., 53:1146-1154

Harvey, W.R. (1990). Mixed Model Least-Square and Maximum Likelihood Computer Program. University of Columbus, Ohio, U.S.A.

Harvey, W.R. and Bearden, G.D.(1962). Table of expected genetic progress in each of two traits. U.S.D.A., ARS- 20-12.

Hartmann, C.; E., Strandberg; L., Rydhmer; K., Jahansson (2003). Genetic relation of yolk proportion and chick weight with production traits in a White Leghorn line. Br. Poultry Sci., 44 (2):186-191

Khalil, M. H., Hermes, I. H. and Al-Homodan, A. H. 1999. Estimation of heterotic components for growth and livability traits in a cross breeding experiment of Saudi chickens with White Leghorn. Egypt. Poult. Sci., 19 (3): 491-507.

Kosba, M. A., Hassan, G. E., Hassan, M. F., Bahie El-Deen, M. and Hanna, Ghanem, H. (1997). Selection and correlated response for age sexual maturity in Alexandria chicken. 2nd Hungarian-Egyptian Conf., Godollo, 16-19 Sept. 1997

Kosba, M.A.; M. Farghaly; M., Bahie El-Deen; and H.A., Abd-El-Halim (2002). Selection and genetic analysis of some egg production traits in local chickens. Egypt. Poultry Sci. , 22: 681-696. 
Kosba, M.A.; M., Farghaly; M., Bahie El-Deen; and M.M., Iraqi; A.F.M., El-Laban; and H.A., Abd-El-Halim (2006). Genetic trends and evaluation for productive traits in Alexandria chickens. Egypt. Poult. Sci., 26 (IV): 1497-1513.

Mahmoud, T.H.; I.F. Sayed.; Y.H. Madkour and M.M. Honein. (1982). The "Gimmizah" a new breed of chicken. Agric. Res. Rev., Cairo, 60: 51-68.

Mohammed, KH.A. (1997). Improvement of some Egyptian strains of chickens by crossing with egg-type commercial breeds. Second Hungarian - Egyptian Poultry Conf., 16-19 September 1997, Godollo, Hungare part1. Page 171:178.

Nawar, M.M. (1995). A comparative study of some productive traits between some native and foreign breeds of chickens. Ph.D. Tthesis, Fac. of Agric. Minufiya Univ., Egypt.

SAS (2004). Statistical user's Guide. INT., Cary, NC. USA.

Saleh, K. M.; N.S., Isshak; T.H., Mahmoud; and A.A., Debess ( 2002). Selection and correlated response for some production traits in Baheij strain. Egypt. Poultry Sci., 22 (III): 653-664

Saleh, K. and Farghly, M. 1988. The effect of crossbreeding on growth traits in chicken. Com. Sci \& Dev. Res., 22: 153-170.

Saleh, K., H.H. Younis, F. Abd El-Ghany and A. Enyat Hassan (2006). Selection and correlated response for egg production traits in Inshas and Silver Montazah strains of chickens. Egypt. Poultry Sci., 26: 749-770

Siegel PB and Dunnington EA (1985). Reproductive complications associated with selection for broiler growth. Pages 59-71 in Poultry Genetics and Breeding. W. G. Hill, J. M.Manson, and D. Hewitt, ed. Br. Poult. Sci. Ltd., Longman Group, Harlow, UK.

Rishell, W. A.(1997). Genetic selection strategies for the future breeding and genetics historical perspective. Poultry Sci., 76: 1057-1061.

Rizkalla, H. E., A.Z. Wagdy and E. F. Abd El-Hamied (2002). The significance of early body measurements in Fayoumi chickens compared with a standard breed R.I.R. and some developed local strains. J.Agric. Sci., Mansoura Univ., 27(2): 869-879

Younis, H. H. and Abd El -Ghany, .A. (2003).Productive and reproductive performance of four local strains during winter and summer seasons. Egypt. Poult. Sci. J., 23 : 893-910.

Younis, H.H.; and F.A. Abd EL-Ghany (2004). Direct and correlated response to selection for egg number in Silver Montazah chickens. Egypt. Poult. Sci., 24: 701-718. 


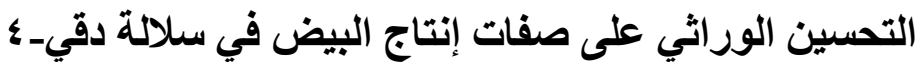 r ـ الاستجابة المرتبطة، المكافئ الوراثي والمظهري لصفئ لصفات النمو}

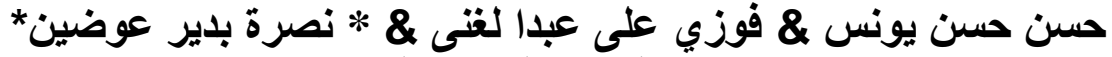

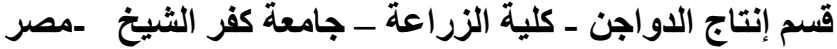 \\ *معه بحوث الإنتاج الحيواني ـ مزكز البحوث الزراعية ـ وزارة الزراعة ـ ـ مصر.}

أجريت هذه الدراسة خلال ثناث أجيال متتالية وكان الهدف الرئيسي هو التحسين

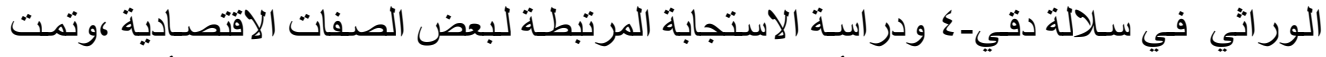

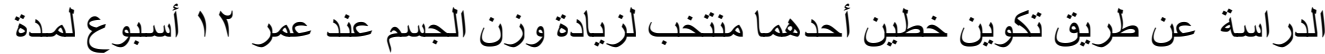

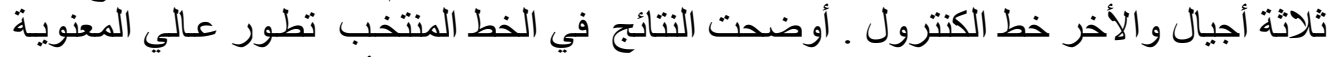

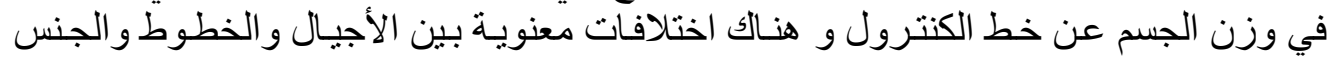

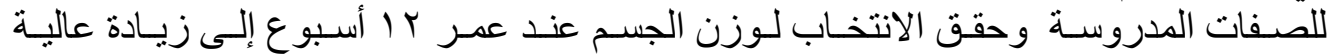

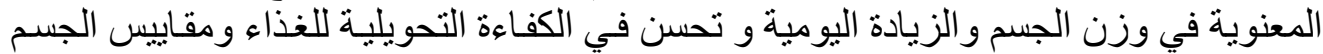

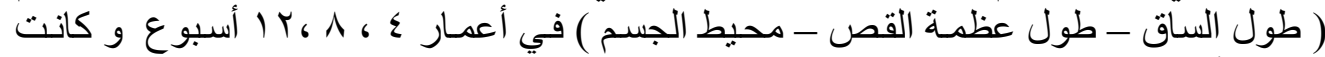

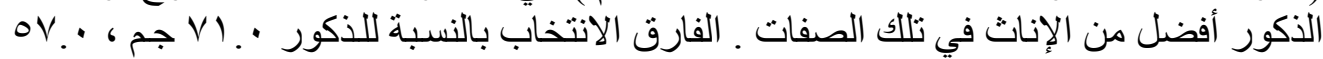

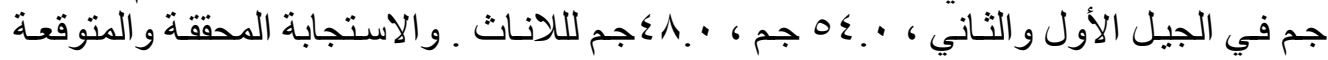

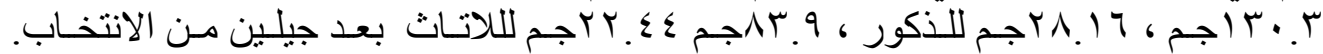

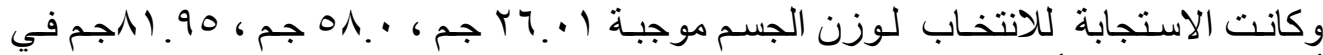

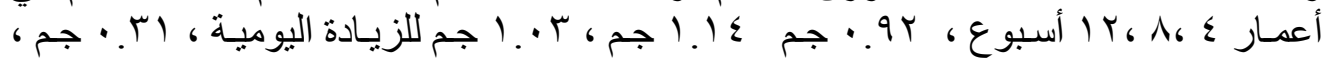

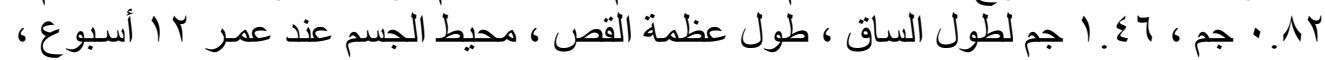

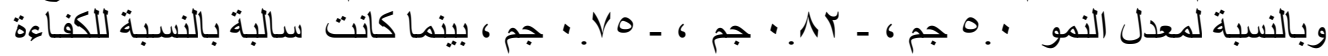

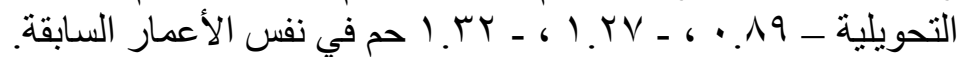

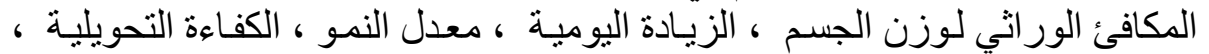

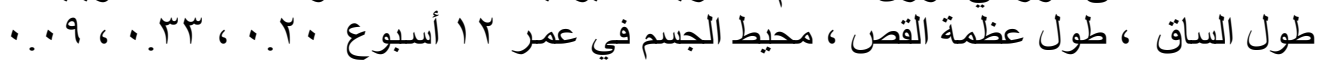

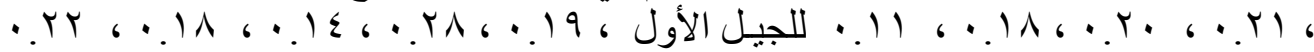

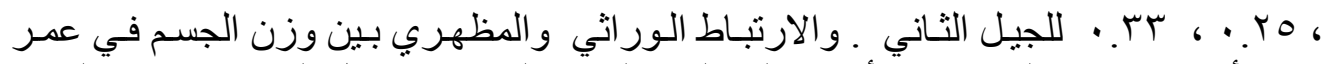

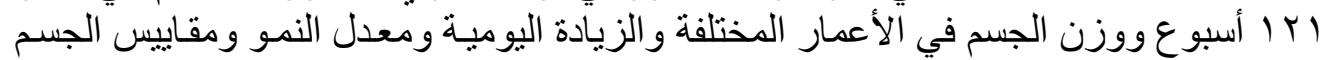

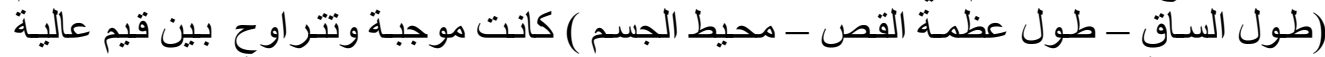

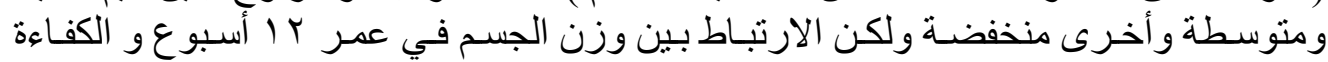
التحويلية كانت سالبة. التوصية: ينصح بمو اصلة الانتخاب المبانشر في سلالة دجاج دقي- ـ لوزن الجسم في الأعمار المختلفة لتحقيق المزيد من التحسن في معدل اداء ومقاييس النمو الأخرى. 